\title{
Problems and Countermeasures of Human Resource Management in Small and Medium Sized Enterprises
}

\author{
Yingdong Chen ${ }^{1, a}$, Jian Xing ${ }^{1, b}$, Xiaocheng Sun ${ }^{* 1, c}$ \\ ${ }^{1}$ School of management, Dalian Polytechnic University, Dalian, China
}

\begin{abstract}
Due to their own attributes, small and medium-sized enterprises are quite different from large enterprises in various aspects of enterprise management, especially in human resource management. In mature large enterprises, there is a relatively perfect human resource management system, while in small and medium-sized enterprises, most enterprises have a set of human resource management mode, but on the whole, it is not perfect and has many problems. This paper takes small and medium-sized enterprises as the research foothold, studies the problems in human resource management, discusses the relevant research countermeasures, and provides suggestions and reference for the human resource management of small and medium-sized enterprises.
\end{abstract}

\section{INTRODUCTION}

Small and medium-sized enterprises are an important force to promote economic development and employment. At present, the human resource management mode of most small and medium-sized enterprises is not perfect, and there is still room for further improvement. This kind of space can be reflected in all aspects of human resource management of small and medium-sized enterprises, such as talent recruitment, training, remuneration.We should improve the human resource management system of small and medium-sized enterprises,so as to ensure the realization of organizational goals Now with the maximization of member development.

\section{CURRENT SITUATION OF HUMAN RESOURCE MANAGEMENT IN SMALL AND MEDIUM SIZED ENTERPRISES}

At present, the human resource management of small and medium-sized enterprises has relatively backward management mode and slow development.

\section{A. Human resource management system is gradually formed}

Different from large enterprises, the human resource management of small and medium-sized enterprises has its particularity. At present, in the vast majority of small and medium-sized enterprises, are gradually aware of the importance of human resource management, and as one of the ways to enhance the competitiveness of enterprises, therefore, small and medium-sized enterprises are walking on the road of human resource management system construction, and there is still a long way to go. On the whole, the progress of the construction of human resource management system is relatively slow. Many enterprise managers have not realized that the development of enterprises is inseparable from human resource management. Therefore, the lack of understanding of managers is also a major status quo of human resource management construction in small and medium-sized enterprises.

\section{B. The human resource management system is not clear enough}

Many small and medium-sized enterprises' human resource management system has not been recognized by its employees, or in other words, many enterprise employees can not feel the enterprise's human resource management system. Many small and medium-sized enterprises are still backward in thinking, and they are still in accordance with the traditional management mode, which leads to problems such as weak staff enthusiasm and low enterprise operation efficiency. Although some small and medium-sized enterprises apply the human resource management mode of those large-scale enterprises to themselves, there are great differences between large-scale enterprises and small and medium-sized enterprises. Therefore, the human resource management mode of the two enterprises is very different Also different, small and medium-sized enterprises have their own management mode, and many small and medium-sized enterprise managers

52208890@qq.com, ${ }^{\mathrm{b}} 1003869513 @$ qq.com, ${ }^{\mathrm{c} a m a n t @ \text { sina.com }}$ 
have not enough understanding of this aspect.

\section{Different regional environment leads to the inconsistency of human resource management construction}

Due to regional and environmental differences, small and medium-sized enterprises in different regions and environments have different pace in the construction of human resource management system. In areas with good economic development, the construction of human resource management of small and medium-sized enterprises is also relatively fast. In areas with relatively backward economic development, the construction of human resource management of small and medium-sized enterprises is slow. Take China as an example, there are big differences in the construction of human resources management between the small and medium-sized enterprises in the north and the south, and the small and medium-sized enterprises in the East and the West. Moreover, due to the different environment, their human resource management modes are also different. Therefore, they can not implement according to the same standard. Enterprises can only find enterprises similar to their own enterprises to learn from, and more importantly, they have to explore by themselves, which is more difficult.

TABLEI. INVESTIGATION ON TURNOVER OF MEDIUM AND SMALL ENTERPRISES IN CENTRAL AND WESTERN CHINA

\begin{tabular}{|c|c|c|}
\hline region & $\begin{array}{c}\text { Number of enterprises } \\
\text { surveyed }\end{array}$ & $\begin{array}{c}\text { Turnover (100 million } \\
\text { yuan) }\end{array}$ \\
\hline east & 50 & 13 \\
\hline wast & 50 & 42 \\
\hline total & 100 & 55 \\
\hline \multicolumn{2}{|c|}{ a }
\end{tabular}

\section{Problems in human Resource MANAGEMENT OF SMALL AND MEDIUM SIZED ENTERPRISES}

According to the current situation of human resource management in small and medium-sized enterprises, we can analyze the problems in human resource management of small and medium-sized enterprises.

\section{A. The construction of human resource management system is slow}

Compared with large enterprises, small and medium-sized enterprises have the characteristics of insufficient resources, insufficient funds and low attraction of talents due to their large number and special nature. Therefore, the construction of human resource management system is relatively slow. With the development of society, people's thinking has also changed. We can't deal with the changes of the times according to the old mode. We must have a new human resource management mode which is suitable for the development of the times. Only in this way can we improve the operation efficiency of enterprises, enhance the enthusiasm of employees and enhance the competitiveness of enterprises. However, due to various factors, the current human resource management of small and medium-sized enterprises has been improved The pace of the construction of the management system is slow.

\section{B. Employees' perception of human resource management is not high}

Human resource management, in the final analysis, is designed for people and employees. Therefore, whether employees can feel the human resource management mode of an enterprise is a witness of the success of enterprise human resource management. At present, the vast majority of employees in small and medium-sized enterprises can not feel the human resource management mode of the enterprise. Even though these enterprises have a set of human resource management mode, the implementation of staff recruitment, performance management, training and other aspects is not enough, which makes the staff work enthusiasm is not high, and the sense of gain is not strong. Therefore, the perception degree of employees to enterprise human resource management is not high High is one of the important problems in human resource management of small and medium-sized enterprises.

\section{Regional and environmental differences lead to different progress of human resource management construction}

For the construction of human resource management of small and medium-sized enterprises, we should focus on the vast majority of small and medium-sized enterprises. However, due to the differences of regions and environments, there are great differences in the construction of human resource management of small and medium-sized enterprises in different regions and environments, mainly in the progress. On the whole, at present, the economic development of the northern region lags behind that of the southern region, and the economic development of the western region lags behind that of the eastern region. Under the different background of the economic environment, the enterprise's own construction is also different, which is also reflected in the human resource management. In this field, the overall level of human resource management of small and medium-sized enterprises is lagging behind, and the difference in the progress is as follows It is an important issue for the development of human resource management in small and medium-sized enterprises. 


\section{ANALYSIS ON THE DEVELOPMENT OF HUMAN RESOURCE MANAGEMENT IN SMALL AND MEDIUM SIZED ENTERPRISES}

In view of some problems in the current human resource management of small and medium-sized enterprises, combined with the actual situation, the Countermeasures for the development of human resource management of small and medium-sized enterprises are analyzed, including the following aspects.

\section{A. Improve the knowledge of human resource management of small and medium-sized enterprises managers}

The construction of human resource management system in small and medium-sized enterprises needs enterprise managers to take the lead. Therefore, whether the enterprise managers are willing and able to carry out the construction of human resource management system is an important prerequisite for the construction of enterprise human resource management system. The number of small and medium-sized enterprises is huge, the quality is uneven, and the level of enterprise managers is also different. It is necessary to enhance the awareness of the managers of small and medium-sized enterprises for the construction of human resources management. Through lectures and training, they can improve their understanding and ability, and are willing and able to carry out the construction of human resources management in enterprises.

\section{B. Improve the application of enterprise human resource management mode in employees}

Enterprise human resource management mode is to be applied to employees. Through the optimization of employee recruitment, employee training, performance management and other aspects, the satisfaction of employees to the company's management system can be improved, so as to improve the enthusiasm of employees and the competitiveness of the company, so as to form a virtuous circle Working hours can attract more talents and retain more talents. In this way, the enterprise is a dynamic enterprise, a developing enterprise and a promising enterprise.

\section{Overall development of human resource management of small and medium-sized enterprises under different regional environment}

In areas with good economic environment, the human resource management of small and medium-sized enterprises is relatively more perfect. In areas with backward economic environment, human resource management of small and medium-sized enterprises is also relatively backward. However, enterprises with backward human resource management can not completely copy good enterprises. Because of different regions and environments, talent reserves and policy environment are different, and human resource management is backward. In order to serve the enterprises, enterprises should draw lessons from the enterprises which have done well in human resource management, and at the same time, they must fully combine their own enterprise reality, and according to the actual situation, formulate the human resource management system in line with the actual situation of their own enterprises, so as to serve the enterprises.

\section{Conclusion}

In terms of human resource management, small and medium-sized enterprises still have a long way to go. In the development of human resource management of small and medium-sized enterprises, enterprises must be based on reality, based on problems, and according to the actual situation, improve the understanding of human resource management of small and medium-sized enterprises managers, improve the application degree of enterprise human resource management mode in employees, and coordinate the development of small and medium-sized enterprise people in different geographical environment Human resource management, in order to improve the pace of construction of human resource management in small and medium-sized enterprises, optimize the human resource management system of small and medium-sized enterprises, and make them develop better.

\section{REFERENCES}

1. Wei min. problems and Countermeasures in human resource management of enterprises [J]. Industry and Technology Forum, 2020, 19 (23): 212-213

2. $\mathrm{Hu}$ Zhufen. Thinking on human resource salary management of enterprises in the new era $[\mathrm{J}]$. Modern marketing (Business Edition), 2020 (12): 4-5.

3. Zhao Juan. Analysis of the effectiveness of human resource recruitment in small and medium-sized enterprises [J]. Modern marketing (Business Edition), 2020 (12): 8-9.

4. Cao Jimei. Research on the construction and practice of human resource incentive mechanism in small and medium-sized enterprises [J]. Modern marketing (Business Edition), 2020 (12): $10-11$.

5. Jiang pengpeng. Effective application of political work in human resource management [n]. Entrepreneur daily, November 26, 2020 (003).

6. Yu Hui. Research on enterprise human resource management based on big data [J]. Business news, 2020 (33): 195-196.

7. Shasha. Analysis of problems and Countermeasures in training management of small and medium-sized enterprises [J]. Business news, 2020 (32): 102-103. 